\title{
Pengaruh Substrat Afkir Jamur Kayu Dan Metode Pembuatan Bibit Yang Berbeda Pada Pertumbuhan Dan Produksi Jamur Merang (Volvariella Volvaceae) Dengan Sistem Nampan Bersusun
}

\author{
Agus Sugianto', Anis Sholihah' dan Siti Muslikah' \\ ${ }^{1}$ Dosen Agroteknologi, Fakultas Pertanian, Universitas Islam Malang \\ JI. MT. Haryono No. 193 Malang \\ Korespondensi :agus.sugianto@unisma.ac.id
}

\begin{abstract}
Abstrak
Jamur merang merupakan salah satu jenis jamur yang banyak digunakan sebagai olahan makanan, permintaan jamur merang terus meningkat menyebabkan nilai ekonominya juga terus meningkat. Selama ini budidaya jamur merang membutuhkan tempat yang luas sehingga perlu dilakukan terobosan inovasi budidaya dengan sistem nampan. Kandungan mineral limbah media jamur kayu yang tersisa dapat digunakan sebagai campuran media tumbuh jamur merang. Pembuatan bibit metode tanam eksplan langsung baru sebatas bibit jamur kayu dan belum pernah digunakan pada jamur merang maka perlu dilakukan penelitian lebih lanjut. Tujuan dari penelitian ini untuk mengetahui respon pertumbuhan dan produksi jamur merang serta mengetahui analisis nilai usaha tani. Rancangan yang digunakan RAL faktorial dua faktor, faktor pertama yaitu penambahan substrat afkir jamur kayu dan faktor kedua adalah metode pembuatan bibit yang berbeda. Masing-masing perlakuan diulang sebanyak 4 kali. Hasil penelitian menunjukkan secara umum tidak banyak terjadi interaksi antar perlakuan, namun secara terpisah perlakuan metode pembuatan bibit yang berbeda memiliki masa pertumbuhan yang berbeda, pada metode bibit TEL (tanam eksplan lagsung) memiliki periode masa panen total selama 20 hari dan metode BMM (biakan murni mieselum) 24 hari. Hasil analisis usaha tani penggunaan limbah jamur 40\% memiliki nilai usaha tani paling tinggi dalam 11 periode tanam.
\end{abstract}

Kata Kunci : Jamur Merang, Limbah Baglog Afkir, Sistem Nampan Bersusun.

\begin{abstract}
Straw mushroom is one type of fungus that is widely used as processed food, the demand for mushrooms continues to increase, causing its economic value to continue to increase. During this time the cultivation of merang mushrooms requires a large place so that it needs to be a breakthrough innovation in cultivation with a tray system. The remaining mineral content of wood mushroom media can be used as a media mixture of growing mushroom. Making seedlings for direct explant planting methods is limited to wood mushroom seedlings and has never been used on straw mushrooms, further research needs to be done. The purpose of this study was to determine the response of growth and production of mushroom and to find out the analysis of farm value. The design used in factorial RAL is two factors, the first factor is the addition of wood mushroom substrate rejections and the second factor is the method of making different seeds. Each treatment was repeated 4 times. The results showed that in general there was not much interaction between treatments, but separately the treatment of different seedling methods had different growth periods, the TEL seed method had a total harvest period of 20 days and a BMM method of 24 days. The results of farming analysis using $40 \%$ mushroom waste have the highest farming value in 11 planting periods.
\end{abstract}

Kata Kunci : straw mushroom, Residual Baglog Waste, Compiled Tray System. 
Pendahuluan

Jamur merang (Volvariella

volvacea L.) merupakan salah satu jenis jamur yang banyak digunakan sebagai bahan maupun olahan makanan. Rasa, tekstur, dan kandungan gizi yang tinggi menyebabkan jamur merang semakin banyak digemari oleh seluruh lapisan masyarakat mulai dari lapisan menengah kebawah hingga menengah keatas, hal ini mendorong permintaan yang besar terhadap ketersediaan jamur merang dan menyebabkan nilai ekonominya juga terus meningkat. Atas dasar tersebut tidak sedikit masyarakat perkotaan yang ingin melakukan budidaya jamur merang akan tetapi terkendala oleh kurangnya pengetahuan masyarakat tentang teknik budidaya jamur merang dan juga terkendala oleh tempat budidaya, karena selama ini budidaya jamur merang memerlukan tempat yang luas dan peralatan yang cukup banyak. Atas dasar tersebut maka diperlukanlah sebuah terobosan inovasi teknologi tepat guna dalam melakukan budidaya jamur merang bagi masyarakat perkotaan yang ingin melakukan budidaya jamur merang namun terkendala oleh permasalahan diatas..

Limbah baglog jamur kayu memiliki kandungan lignin dan salulosa yang cukup tinggi. Lignin dan selulosa merupakan zat yang berfungsi sebagai penyusun sel yang terdapat di dalam kayu. Sugianto (2015) menerangkan kandungan mineral limbah media jamur kayu mengalami peningkatan setelah panen terutama setelah panen pertama, panen kedua dan panen ketiga terus mengalamai peningkatan yaitu Protein 9.15\%, Air 12,26\%, Abu 32,35\%, Kalsium 1,45\%, Phosphor 0,39\%, Lemak 0,40\%, dan NaCL 0,7\%. Tingginya kandungan mineral limbag baglog jamur kayu sehinga dapat digunakan sebagai campuran substrat tanam jamur merang.

Berdasarkan penelitian yang telah dilakukan pembuatan bibit metode tanam eksplan langsung (TEL) memiliki kecepatan lebih baik untuk memenuhi substrat tanam dan memiliki ketahanan yang lebih baik terhadap kontaminasi (Hafifi, 2013). Akan tetapi selama ini pembuatan bibit metode tanam eksplan langsung baru sebatas bibit jamur tiram dan belum pernah digunakan pada jamur merang maka perlu dilakukan penelitian lebih lanjut.

Objek penelitian ini adalah substrat tanam jerami padi dicampur dengan limbah baglog jamur kayu dan dikombinasikan dengan metode pembuatan bibit yang berbeda. Namun belum diketahui sampai berapa persen tambahan limbah jamur kayu tersebut mampu menghasilkan badan buah 
jamur yang optimum. Maka perlu perlu dilakukan penelitian lebih lanjut untuk mengetahui komposisi yang tepat.

\section{Bahan dan Metode}

Penelitian ini dilaksanakan di Laboratorium Budidaya jamur Agroteknologi Fakultas Pertanian Universitas Islam Malang pada bulan April sampai dengan bulan Mei 2018. Lokasi ini terletak pada ketinggian 550 $\mathrm{m}$ dpl, suhu harian rata-rata $25-27^{\circ} \mathrm{C}$.

Alat yang digunakan adalah: sabit, karung, ember, terpal/plastik, kompor gas, LPG, Drum, Autoclave, Laminar Air Flow (LAF), botol saos, thermometer, hygrometer, beaker glass, hand sprayer, bunsen, kapas, karet penutup botol, pinset, sendok bibit, scalpel, karet gelang, timbangan, $\mathrm{pH}$ meter, mistar, plastik rol bening 0,05 $\mathrm{mm}$, dan jangka sorong. Bahan yang digunakan adalah jerami padi, limbah baglog jamur kayu, alkohol 90\%, spirtus, kalsium karbonat $\left(\mathrm{CaCO}_{3}\right)$, bekatul, dextrose, agar-agar, kentang, dan bibit $F_{2}$ jamur merang (Volvariella volvacea) yang dibuat dengan menggunakan metode TEL (Tanam Eksplan Langsung) dan BMM (Biakan Murni Miselium).

Rancangan penelitian ini Rancangan Acak Lengkap (RAL) Faktorial dua faktor, faktor pertama penambahan substrat akfir jamur kayu yang terdiri dari 5 level: $L_{0}=0 \%$ limbah baglog jamur kayu, $L_{1}=10 \%$ limbah baglog jamur kayu, $L_{2}=20 \%$ limbah baglog jamur kayu, $L_{3}=30 \%$ limbah baglog jamur kayu, $L_{4}=40 \%$ limbah baglog jamur kayu. Factor kedua metode pembuatan bibit yang berbeda yang terdiri dari 2 level: $M_{1}$ (TEL) $M_{2}$ (BMM). Dari kedua faktor tersebut diperoleh 10 kombinasi perlakuan yang diulang sebanyak 4 kali.

Variabel yang diamati setelah inokulasi hingga panen meliputi: Kemampuan miselium memenuhi media (hsi), waktu pertama muncul badan buah (Pinhead) (hsi), waktu pertama panen (hsi), panjang badan buah $(\mathrm{cm})$, jumlah total seluruh badan buah jamur merang (buah), bobot segar total badan buah $(\mathrm{g})$, periode masa panen total (hari), nilai Efisiensi Biologi pada tiap perlakuan dapat diketahui dengan cara dihitung mengunakan rumus berikut ini : $E B=$ Bobot segat total panen (g) : Bobot Substrat Awal $\mathrm{x}$ $100 \%$, dan analisis usaha tani dilakukan untuk mengetahui kelayakan budidaya jamur merang.

Data yang didapat dianalisis dengan uji tara 5\% (ANOVA). Jika terdapat pengaruh yang nyata maka akan dilanjutkan dengan uji BNJ 5\% untuk mengetahui perbedaan tiap-tiap perlakuan. 
Hasil dan Pembahasan

\section{Kecepatan Miselium Memenuhi Media}

Hasil penelitian menunjukkan bahwa tidak terdapat interaksi antara penambahan substrat afkir jamur kayu dan metode pembuatan bibit yag berbeda terhadap variabel pertumbuhan, kecepatan miselium memenuhi media (Tabel 1). Secara terpisah metode pembuatan bibit berpengaruh nyata terhadap kecepatan miselium memenuhi media. Rata-rata kecepatan miselium terlihat pada Tabel 1.

Tabel 1.Rata-Rata Kecepatan Miselium Memenuhi Media

\begin{tabular}{cc}
\hline Perlakuan & $\begin{array}{c}\text { Rata-rata Lama Miselium } \\
\text { Memenuhi Media (hsi) }\end{array}$ \\
\hline $\mathrm{L}_{0}$ & 4,00 \\
$\mathrm{~L}_{1}$ & 3.63 \\
$\mathrm{~L}_{2}$ & 3.50 \\
$\mathrm{~L}_{3}$ & 3.25 \\
$\mathrm{~L}_{4}$ & 3.25 \\
\hline $\mathrm{BNJ}(5 \%)$ & $\mathrm{TN}$ \\
\hline $\mathrm{M}_{1}$ & $2.25 \mathrm{a}$ \\
$\mathrm{M}_{2}$ & $4.80 \mathrm{~b}$ \\
\hline $\mathrm{BNJ}(5 \%)$ & 1.03 \\
\hline Keterangan:- - Angka-angka yang diikuti huruf yang \\
sama menunjukkan tidak berbeda \\
nyata pada uji BNJ 5\%. -TN: Tidak \\
Nyata. (hsi) : Hari Setelah \\
Inokulasi
\end{tabular}

Tabel 1 menunjukkan perlakuan $M_{1}$ miselium lebih cepat memenuhi media dibanding $\mathrm{M}_{2}$ pada rata-rata hari ke 2.25 (hsi) miselium telah memenuhi media. Hal tersebut menunjukkan pertumbuhan miselium yang cukup bagus karena miselium memenuhi media pada hari ke- 2 .

Hafifi (2013) mengungkapkan, pengunaan bibit TEL memberikan pengaruh selisih lebih antara metode yang digunakan, yaitu memberikan pengaruh lebih cepat dibandingkan dengan metode BMM. Selisih kedua metode tersebut mencapai kisaran 0.84 sampai dengan 1.96 hari hal tersebut menunjukkan miselium dari BMM lebih lambat dibandingkan dengan metode TEL. Selisih pertumbuhan miselium kedua metode tersebut mencapai 2 hari. Berbeda jika dilakukan perhitungan antara generasi bibit, maka metode TEL cenderung stabil dibandingkan metode BMM. Hal ini menunjukan bahwa metode TEL memiliki daya adaptasi yang lebih baik (Sugianto, 2017).

\section{Waktu Muncul Badan Buah}

Hasil analisis

ragam menunjukkan tidak terdapat interaksi penambahan substrat jamur kayu afkir dan metode pembuatan bibit yang berbeda namun secara terpisah perlakuan metode bibit yang digunakan memberikan pengaruh nyata terhadap waktu muncul badan buah seperti yang terlihat pada Tabel 2. 
Tabel 2. Rata-rata Waktu Muncul Badan Buah (Pindhead) Pertama

\begin{tabular}{cc}
\hline Perlakuan & $\begin{array}{c}\text { Muncul Badan Buah } \\
\text { Pertama (hsi) }\end{array}$ \\
\hline $\mathrm{L}_{0}$ & 5.75 \\
$\mathrm{~L}_{1}$ & 5.50 \\
$\mathrm{~L}_{2}$ & 5.50 \\
$\mathrm{~L}_{3}$ & 5.50 \\
$\mathrm{~L}_{4}$ & 5.25 \\
\hline $\mathrm{BNJ}(5 \%)$ & $\mathrm{TN}$ \\
\hline $\mathrm{M}_{1}$ & $4.20 \mathrm{a}$ \\
$\mathrm{M}_{2}$ & $6.80 \mathrm{~b}$ \\
\hline $\mathrm{BNJ}(5 \%)$ & 1.21 \\
\hline Keterangan: - Angka-angka yang diikuti huruf yang \\
\multicolumn{2}{c}{ sama menunjukkan tidak berbeda } \\
nyata pada uji BNJ $5 \%$. TN: Tidak \\
Nyata. (hsi) : Hari Setelah \\
Inokulasi
\end{tabular}

Pada Tabel 2 menunjukkan perlakuan $M_{1}$ (TEL) waktu muncul badan buah (pindhead) pertama lebih cepat daripada perlakuan $\mathrm{M}_{2}$ (BMM). Metode $M_{1}$ muncul badan buah ratarata pada hari ke 4.20 (hsi) sedangkan $\mathrm{M}_{2}$ rata-rata pada hari ke 6 (hsi). Hal tersebut menunjukkan semakin cepat miselium memenuhi substrat tanam maka akan semakin cepat pula pertumbuhan calon badan buah (pinhead). Selaras dengan apa yang dikemukkan oleh Sumiati dkk. (2009) bahwa semakin cepat penyebaran miselium maka akan semakin cepat pula dalam pembentukan badan buah.

\section{Waktu Panen Pertama}

$$
\text { Hasil analisis ragam }
$$

menunjukkan tidak terdapat interaksi penambahan substrat jamur kayu afkir dan metode pembuatan bibit yang berbeda namun secara terpisah perlakuan metode bibit yang digunakan memberikan pengaruh nyata terhadap waktu panen pertama seperti yang terlampir pada Tabel 3.

Tabel 3. Rata-rata Hari Panen Pertama

\begin{tabular}{cc}
\hline Perlakuan & $\begin{array}{c}\text { Rata-rata hari panen } \\
\text { pertama (hsi). }\end{array}$ \\
\hline $\mathrm{L}_{0}$ & 8.13 \\
$\mathrm{~L}_{1}$ & 7.38 \\
$\mathrm{~L}_{2}$ & 7.50 \\
$\mathrm{~L}_{3}$ & 7.75 \\
$\mathrm{~L}_{4}$ & 7.60 \\
\hline $\mathrm{BNJ}(5 \%)$ & $\mathrm{TN}$ \\
\hline $\mathrm{M}_{1}$ & $6.35 \mathrm{a}$ \\
$\mathrm{M}_{2}$ & $9.00 \mathrm{~b}$ \\
\hline BNJ (5\%) & 1.43 \\
\hline Keterangan: - Angka-angka yang diikuti huruf yang \\
\\
sama menunjukkan tidak berbeda \\
nyata pada uji BNJ 5\%. -TN: Tidak \\
Nyata. \\
(hsi) : Haki Setelah \\
Inokulasi
\end{tabular}

Tabel 3 menunjukkan perlakuan $M_{1}$ (TEL) waktu panen pertama (hsi) lebih cepat daripada perlakuan $M_{2}$ (BMM) pada rata-rata hari ke 6.35 (hsi).

\section{Panjang Badan Buah}

$$
\text { Hasil analisis ragam }
$$
menunjukkan tidak terdapat interaksi penambahan substrat jamur kayu afkir dan metode pembuatan bibit berbeda namun secara terpisah perlakuan penambahan substrat jamur kayu afkir memberikan pengaruh nyata terhadap panjang badan buah. seperti yang terlihat pada Tabel 4. 
Tabel 4. Rata-rata Panjang Badan Buah

\begin{tabular}{cc}
\hline Perlakuan & $\begin{array}{c}\text { Rata-rata Panjang Badan } \\
\text { Buah (cm) }\end{array}$ \\
\hline $\mathrm{L}_{0}$ & $2.83 \mathrm{a}$ \\
$\mathrm{L}_{1}$ & $2.85 \mathrm{ab}$ \\
$\mathrm{L}_{2}$ & $2.87 \mathrm{ab}$ \\
$\mathrm{L}_{3}$ & $2.99 \mathrm{~b}$ \\
$\mathrm{~L}_{4}$ & $2.93 \mathrm{~b}$ \\
\hline $\mathrm{BNJ}(5 \%)$ & 0.14 \\
\hline $\mathrm{M}_{1}$ & 2.87 \\
$\mathrm{M}_{2}$ & 2.92 \\
\hline $\mathrm{BNJ}(5 \%)$ & $\mathrm{TN}$ \\
\hline Keterangan: - Angka-angka yang diikuti huruf yang \\
\multicolumn{2}{c}{ sama menunjukkan tidak berbeda } \\
nyata pada uij BNJ $5 \%$. TN: Tidak \\
Nyata. (hsi) : Hari Setelah \\
Inokulasi &
\end{tabular}

Pada Tabel 4 menunjukkan perlakuan $L_{3} \quad(30 \%$ substrat afkir) memiliki panjang badan buah paling tinggi yakni $2.99 \mathrm{~cm}$ namun tidak berbeda nyata dengan perlakuan $\mathrm{L}_{4}$ ( $40 \%$ substrat afkir) $2.93 \mathrm{~cm}, \mathrm{~L}_{2}(20 \%$ substrat afkir) $2.87 \mathrm{~cm}$ dan $\mathrm{L}_{1}(10 \%$ substrat afkir) $2.85 \mathrm{~cm}$ namun berbeda nyata denggan perlakuan $L_{0}$ (tanpa substrat afkir) memiliki panjang paling rendah yakni $2.83 \mathrm{~cm}$.

\section{Jumlah Total Badan Buah}

$$
\text { Hasil analisis ragam }
$$

menunjukkan tidak terdapat interaksi nyata penambahan substrat jamur kayu afkir dan metode pembuatan bibit berbeda pada jumlah total badan buah demikian juga secara terpisah tidak menunjukkan pengaruh yang nyata. Rata-rata jumlah total badan buah tersaji dalam Tabel 5.
Tabel 5. Rata-rata Panjang Badan Buah

\begin{tabular}{cc}
\hline Perlakuan & $\begin{array}{c}\text { Jumlah total badan buah } \\
\text { (buah) }\end{array}$ \\
\hline $\mathrm{L}_{0}$ & 24.25 \\
$\mathrm{~L}_{1}$ & 26.50 \\
$\mathrm{~L}_{2}$ & 26,00 \\
$\mathrm{~L}_{3}$ & 25.13 \\
$\mathrm{~L}_{4}$ & 27,00 \\
\hline BNJ (5\%) & $\mathrm{TN}$ \\
\hline $\mathrm{M}_{1}$ & 26.80 \\
$\mathrm{M}_{2}$ & 24.75 \\
\hline BNJ (5\%) & $\mathrm{TN}$ \\
\hline Keterangan: - Angka-angka yang diikuti huruf yang \\
\\
sama menunjukkan tidak berbeda \\
nyata pada uji BNJ $5 \%$-TN: Tidak \\
Nyata. & (hsi) : Hari Setelah \\
& Inokulasi
\end{tabular}

\section{Bobot Segar Total Badan Buah}

Hasil analisis ragam menunjukkan tidak terdapat interaksi nyata penambahan substrat jamur kayu afkir dan metode pembuatan bibit berbeda pada bobot segar total badan buah. Rata-rata bobot segar total badan buah tersaji dalam Gambar 1 .

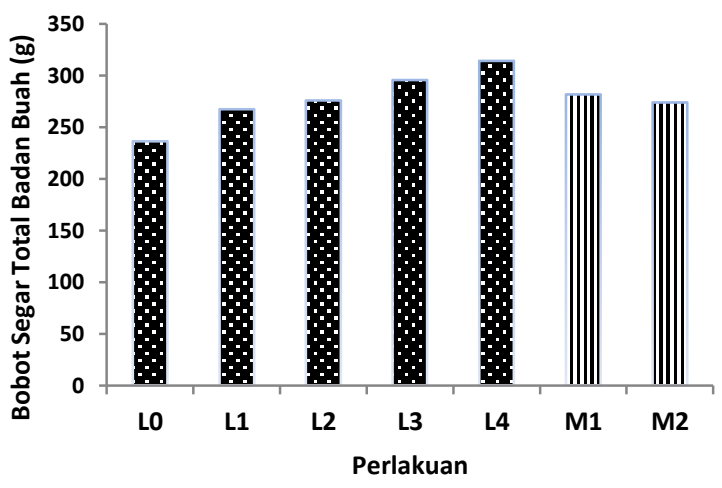

Gambar 1. Rata-rata Total Bobot Segar Total Badan Buah (g)

Pada Gambar 6 terlihat penambahan substrat afkir tidak menunjukkan perbedaan yang nyata namun penambahan $40 \% \quad\left(L_{4}\right)$ cenderung menunjukkan total bobot 
segar badan buah tertinggi dibanding perlakuan yang lain. Perlakuan metode pembuatan bibit juga tidak menunjukkan perbedaan nyata.

\section{Efisiensi Biologi dan Periode Masa Panen Total}

$$
\text { Hasil analisis ragam }
$$
menunjukkan tidak terdapat interaksi nyata penambahan substrat afkir dan metode pembuatan bibit yang berbeda pada nilai efisiensi biologi dan periode masa panen total. Secara terpisah metode pembuatan bibit berpengaruh nyata pada periode masa panen. Ratarata efisiensi biologi dan periode masa panen total terlihat pada Tabel 6 .

Tabel 6. Rata-rata Efesiensi Biologi (\%) dan Periode Masa Panen (hari)

\begin{tabular}{|c|c|c|}
\hline Perlakuan & $\begin{array}{c}\text { Efesiensi } \\
\text { Biologi (\%) }\end{array}$ & $\begin{array}{c}\text { Periode } \\
\text { Masa Panen } \\
\text { (hari) }\end{array}$ \\
\hline$L_{0}$ & 15.73 & 23.13 \\
\hline $\mathrm{L}_{1}$ & 16.44 & 22.75 \\
\hline $\mathrm{L}_{2}$ & 15.74 & 21.75 \\
\hline $\mathrm{L}_{3}$ & 15.74 & 22.75 \\
\hline $\mathrm{L}_{4}$ & 15.70 & 21.25 \\
\hline BNJ (5\%) & $\mathrm{TN}$ & TN \\
\hline $\mathrm{M}_{1}$ & 16.11 & $20.25 \mathrm{a}$ \\
\hline$M_{2}$ & 15.64 & $24.25 \mathrm{~b}$ \\
\hline BNJ (5\%) & TN & 2.43 \\
\hline \multicolumn{3}{|c|}{ 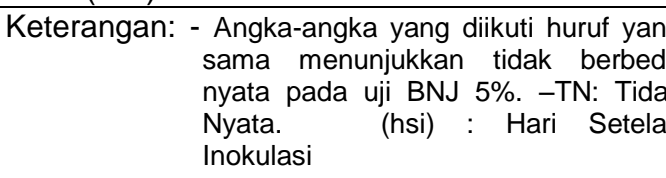 } \\
\hline
\end{tabular}

Periode panen total metode bibit $M_{1}$ (TEL) lebih cepat selesai daripada metode bibit $M_{2}$ (BMM) dimana $M_{1}$ ratarata hari ke- 20,25 (hsi) sedang $M_{2}$ rata- rata selesai pada hari ke- 24,25 lebih lambat 4 hari dibandingkan dengan metode bibit $M_{1}$. Kualitas media yang baik dapat dilihat dengan menghitung nilai efisiensi biologi (EB). Nilai efisiensi biologi memberikan pengertian bahwa dalam substrat tanam jamur seberapa besar yang mampu dirubah menjadi badan buah. Nilai efisiensi biologi (EB) tinggi menunjukkan bahwa dari substrat tanam berhasil dikonversi menjadi badan buah tinggi. Substrat dari jerami gandum menunjukkan efesiensi yang lebih tinggi dibanding substrat dari jerami padi (Kumar et.al, 2016).

Shah et.al. (2004) yang mendapatkan efesiensi biologi tertinggi pada serbuk gergaji tanpa campuran lain yaitu sebesar 64\% dibanding serbuk gergaji dengan campuran jerami gandum (1:1) dan jerami gandum tanpa campuran berturut-turut $44 \%$ dan $58 \%$. Sejalan juga dengan penelitian Kimenju et.al. (2009) serbuk gergaji mempunyai efesiensi biologi sebesar $92 \%$.

\section{Analisis Usaha Tani dan $\mathrm{R} / \mathrm{C}$ ratio}

$$
\text { Hasil analisis ragam }
$$
menunjukkan tidak terdapat interaksi nyata penambahan substrat afkir dan metode pembuatan bibit yang berbeda berbeda pada analisis usaha tani dan R/C rasio. Pendapatan usaha tani dan nilai $\mathrm{R} / \mathrm{C}$ rasio terlihat pada Tabel 7 . 
Tabel 7. Pendapatan Usaha Tani (Rp) dan nilai $\mathrm{R} / \mathrm{C}$ rasio

\begin{tabular}{ccc}
\hline Perlakuan & $\begin{array}{c}\text { Pendapatan } \\
\text { Usaha Tani (Rp) }\end{array}$ & R/C rasio \\
\hline $\mathrm{L}_{0}$ & Rp. 12.977.318 & 1.78 \\
$\mathrm{~L}_{1}$ & Rp. 14.696.963 & 2.00 \\
$\mathrm{~L}_{2}$ & Rp. 15.155.869 & 2.05 \\
$\mathrm{~L}_{3}$ & Rp. 16.240.813 & 2.19 \\
$\mathrm{~L}_{4}$ & Rp. 17.271.100 & 2.32 \\
\hline BNJ (5\%) & $\mathrm{TN}$ & $\mathrm{TN}$ \\
\hline $\mathrm{M}_{1}$ & Rp. 15.482.940 & 2.10 \\
$\mathrm{M}_{2}$ & Rp. 15.053.885 & 2.04 \\
\hline BNJ (5\%) & TN & TN \\
\hline Keterangan: - Angka-angka yang diikuti huruf yang \\
& sama menunjukkan tidak berbeda nyata \\
& pada uji BNJ 5\%. -TN: Tidak Nyata. \\
& (hsi) : Hari Setelah &
\end{tabular}

Penerimaan usaha tani perlakuan $\mathrm{L}_{4} \quad(40 \%$ substrat afkir) memiliki pendapatan tertinggi yakni Rp. 17.271.100 dalam 11 periode tanam atau dalam waktu 1 tahun., demikian juga nilai $R / C$ rasio tertingi terletak pada perlakuan $\mathrm{L}_{4}$ yaitu 2,32 menunjukkan keberhasilan dan kelayakan secara ekonomi usaha budidaya jamur merang layak unuk diterapkan. Sundari (2011) mengungkapkan ukuran ekonomi pada umumnya untuk mengambarkan kinerja sektor dan komoditas agribisnis adalah $\mathrm{R} / \mathrm{C}$ rasio (revenue and cost ratio) yang menunjukan perbandingan antara pendapatan dan modal usaha biaya tani.

\section{Kesimpulan Dan Saran}

Metode pembuatan bibit yang berbeda berperngaruh terhadap pertumbuhan jamur Merang (Volvariella volvaceae) Metode $M_{1}$ (TEL) lebih cepat dalam variabel Kecepatan Miselium memenuhi media, awal muncul badan buah (pindhead) panen pertama dan lama total periode tanam. Sedangkan perlakuan penambahan substrat afkir $L_{4}$ menunjukkan pendapatan Rp. 17.271.100 dalam 11 periode tanam. Disarankan petani menggunakan metode $M_{1}$ (TEL) dalam melakukan usaha budidaya dan penambahan substrat akhir $40 \%$.

\section{Daftar Pustaka}

Hafifi, S. 2013. Uji Efektifitas dan Efisiensi Metode Tanam Eksplan Langsung (TEL) Sebagai Inovasi Pembibitan Jamur Tiram Putih Dibandingkan Dengan Biakan Murni Miselium (BMM).Universirtas islam Malang. Malang.

Kimenju,J.W, G.O.M. Odero, E.W. Mutitu, P.M. Wachira, R.D. Narla and W.M. Muiru. 2009. Suitability of locally available substrates for oyster mushroom (Pleoratus oestreatus) cultivation in Kenya. Asian journal of plant science ISSN 1682-3974 Volume 8(7) :210214.

Kumar U., S. Bikash, A. Dey, S. Kamal and B.P Bhatt. 2016. Energy use efficiency of oyster mushroom production in a selected tribal village. International Journal of Agriculture Sciences. 8 (7) :1069-1071.

Satpal,S., S. Gopal, R.N.Siddarth, P. Bhanu, T. Sonika, K. Ankit, B. Priyanka and P.R. Kumar. 2017b. Effect of different substrates on the growth and yield of oyster mushrooms (Pleurotus djamor). Journal of 
Agriculture Sciences. 9 (4): 3721-3723.

Shah ,Z.A, M. Ashraf and M. Istiaq Ch. 2004. Comparative study and cultivation and yield performance of oyster mushroom (Pleoratus oestreatus) On different substrates (Wheat straw, Leaves, Saw Dust). Pakistan Journal of Nutrition 3(3) :158160.

Sugianto, A. 2013. Inovasi Teknologi TEL Jamur Tiram Putih. ISBN978-602-795-732-9. Aditya
Sugianto, A. 2015. Pengembangan Teknoligi Jamur Kayu Sebagai Pangan Alternatif. Aditya Media Malang.

Sugianto, A. 2017. Pengembangan Teknoligi Jamur Kayu Sebagai Pangan Alternatif. Intimedia. Malang

Sundari, M.T. 2011. Analisis Biaya Dan Pendapatan Usaha Tani Wortel Di Kabupaten Karanganyar. SEPA : Vol. 7 No.2 Pebruari 2011 $: 119-126$

Media. Malang. 278 hal. 